Anna Karolina Gut ${ }^{1}$, Radosław Gut ${ }^{2}$ Aleksandra Rymarz², Agnieszka Woźniak-Kosek ${ }^{4}$

\title{
HEMORRHAGIC FEVER WITH RENAL SYNDROME (HFRS) IN POLAND
}

\section{HFRS (GORĄCZKA KRWOTOCZNA Z ZESPOŁEM NERKOWYM) W POLSCE}

\author{
${ }^{1}$ Dialysis Centre Diaverum, Kraśnicka 100, Lublin \\ ${ }^{2}$ Medical University in Lublin Department of Orthopaedics and Rehabilitation; \\ ${ }^{3}$ Military Institute of Medicine in Warsaw, Department of Internal Diseases, Nephrology and Dialysis; \\ ${ }^{4}$ Military Institute of Medicine in Warsaw, Department of Medical Diagnostics; \\ ${ }^{1} \mathrm{ZOZ}$ Diaverum Kraśnicka w Lublinie \\ ${ }^{2}$ Klinika Ortopedii i Rehabilitacji, Uniwersytet Medyczny w Lublinie \\ ${ }^{3}$ Klinika Chorób Wewnętrznych, Nefrologii i Dializoterapii; Wojskowy Instytut Medyczny CSK MON w Warszawie \\ ${ }^{4}$ Zakład Diagnostyki Laboratoryjnej; Wojskowy Instytut Medyczny CSK MON w Warszawie
}

\begin{abstract}
Hemorrhagic fever with renal syndrome (HFRS) is an acute viral zoonosis occurring due to the hantavirus infection. On the territory it constitutes the only case of viral hemorrhagic fever. The infections occurring in Poland are mainly caused by the Puumala and Dobrava serotypes. The pathogenetic influence of other Hanta serotypes such as Boginia, Nova and Seewis on humans is still unknown.

The endemic territory of the occurrence of the hantavirus infections in Poland is the Podkarpacie region. The morbidity is not high and ranges between 0.02 and 0.14 in every 100000 but professional literature suggests that the data concerning the territory of Poland is underestimated. So far hantavirus infections have not been reported in other areas of Poland yet the presence of the virus may be excluded. In view of literature and the significant occurrence of Hanta antibodies in patients included in the risk group, it may be claimed that the diseases caused by Hanta virus constitute a significant factor influencing the medical status of the group in focus all over the country.
\end{abstract}

Key words: hantavirus, hemorrhagic fever, renal syndrome

\section{STRESZCZENIE}

Gorączka krwotoczna z zespołem nerkowym (HFRS - Hemorrhagic fever with renal syndrome) to ostra choroba odzwierzęca wywoływana przez wirus Hanta. Występuje na terytorium Polski jako jedyna z grupy wirusowych gorączek krwotocznych. Zakażenia w Polsce wywołuje najczęściej serotyp Puumala i Dobrava/Belgrad. Notuje się także wykrycie obecności innych serotypów wirusa Hanta np.: Boginia, Nova i Seewis o nieznanej jeszcze patogenności dla ludzi.

Terenem endemicznego występowania zakażeń wirusem Hanta w naszym kraju jest Podkarpacie. Zapadalność nie jest duża, wynosi od 0,02 do 0,14 na 100 tys., ale istnieje przypuszczenie, że dane z Polski są niedoszacowane, za czym przemawiają informacje zawarte w naukowym piśmiennictwie. Dowodzi ono występowania tego typu wirusa również w innych niż Podkarpacie rejonach kraju, w których dotychczas nie rejestrowano doniesień o zachorowaniach. W świetle znacznego rozpowszechnienia przeciwciał przeciwko wirusom Hanta wśród osób z grup podwyższonego ryzyka słuszna jest teza, że choroba spowodowana wirusami Hanta jest istotnym czynnikiem kształtującym stan zdrowia tych osób w całym kraju.

Słowa kluczowe: wirus Hanta, gorączka krwotoczna, zespót nerkowy 


\section{INTRODUCTION}

Hemorrhagic fever with renal syndrome (HFRS) is an acute zoonotic disease caused by the Hanta virus. It occurs on the territory of Poland as the only one from the group of viral hemorrhagic fevers. Hantavirus (HV), also called Orthohantavirus, is one of the 5 types of the Bunyaviridae family, which includes about 300 species of viruses. Four species from this family: Nairovirus, Phlebovirus, Tospovirus, Bunyavirus are classified as Arboviruses (Arthropod-borne) that are transmitted via arthropods. HV belongs to Roboviruses (Rodent-borne) and is transmitted by small, wild rodents. In Europe, mice and voles constitute the most common vectors. The virus is composed of a lipid envelope containing 3 single-stranded RNA strands with negative ssRNA (-) polarity that form 3 subunits: L segment (large) RNA polymerase encoding, $\mathrm{M}$ segment (medium) encoding Gn and Gc glycoproteins (currently G1 and G2), and the $\mathrm{S}$ (small) segment coding for the nucleocapsid protein (1). The viral genome is $11-12.000$ base pairs in size, the size of the virion is about $80-120 \mathrm{~nm}$.

$\mathrm{HV}$ infection occurs as an acute tubulointerstitial nephritis. The virus infects endothelial cells in the human body. Cell penetration is facilitated by $\beta$-integrin (2). HV replication occurs in the endothelium of the pulmonary vessels and glomerulus, also in macrophages (3). On the basis of research in cell cultures, it was observed that Hantavirus has no cytopathic effect. Increased vascular permeability is an essential mechanism in the pathogenesis of the infection. Consequently, there occurs damage of the kidneys and other organs. The infammation mediators include: nitric oxide and TNF- $\alpha$, released by activated macrophages, and they are responsible for the capillary leak and vasodilatation (4).

Each of the virus species has its own specific biological vector. Animals are infected with the virus in a latent way. Therefore, they do not manifest any symptoms of the disease, but they excrete all the viral molecules with urine, faeces and saliva and people can get infected by inhalation of dust containing the excretion particles.

For Hantaan, Dobrava, Seoul, Saarema and Amur viral species, the vectors is different and it is the rodents of the Murinae family - respectively: for the Hantaan serotype - Apodemus agrarius (field mouse) occurring in China, Korea, Russia and some European countries, for the Dobrava serotype Apodemus flavicollis (forest mouse) occurring in Europe (5). The Seoul type that is spread all over the world is transmitted by rats from the Rattus norvegicus and Rattus rattus species. The Asian Amur serotype is transmitted by the Apodemus.

The above mentioned species initiate a clinical syndrome called HFRS which is characterized by the

\section{WSTĘP}

Gorączka krwotoczna z zespołem nerkowym (HFRS-Hemorrhagic fever with renal syndrome) to ostra choroba odzwierzęca wywoływana przez wirus Hanta. Występuje na terytorium Polski, jako jedyna z grupy wirusowych gorączek krwotocznych. Hantawirus (HV), zwany również Orthohantavirus to jeden z 5 rodzajów rodziny Bunyaviridae, do której należy ok. 300 gatunków wirusów. Cztery rodzaje z tej rodziny: Nairovirus, Phlebovirus, Tospovirus, Bunyavirus klasyfikowane są jako Arbowirusy (Arthropod-borne), czyli przenoszone za pośrednictwem stawonogów, HV należy do Robowirusów (Rodent-borne) i jest przenoszony przez drobne, dziko żyjące gryzonie. W Europie wektorami są najczęściej myszy i nornice. Wirus zbudowany jest $z$ lipidowej otoczki zawierającej 3 jednoniciowe fragmenty łańcucha RNA o ujemnej polarności ssRNA(-) tworzące 3 podjednostki: segment L (large) kodujący RNA polimerazę, segment M (medium) kodujący glikoproteiny Gn i Gc (obecnie G1 i G2), oraz segment S (small) kodujący proteiny nukleokapsydu (1). Genom wirusa ma wielkość 11-12.000 par zasad, wielkość wirionu wynosi ok. 80-120nm.

Zakażenie HV przebiega jako ostre cewkowo-śródmiąższowe zapalenie nerek. Wirus zakaża w organizmie ludzkim komórki śródbłonka. Wniknięcie do komórek ułatwiają $\beta$-integryny (2). Replikacja HV odbywa się w śródbłonku naczyń płucnych i kłębuszków nerkowych, także w makrofagach (3). Na podstawie badań w hodowlach komórkowych zaobserwowano, że Hantavirus nie ma efektu cytopatycznego. Zwiększona przepuszczalność naczyń jest podstawowym mechanizmem w patogenezie zakażenia. Dochodzi do uszkodzenia nerek i innych narządów. Mediatory zapalenia: tlenek azotu i TNF- $\alpha$, uwalniane przez aktywowane makrofagi są odpowiedzialne za przeciek naczyniowy (ang. capillary leak) i wazodilatację (4).

Każdy z gatunków wirusa ma swój specyficzny wektor biologiczny. Zwierzęta zakażają się wirusem w sposób latentny. Nie prezentując objawów chorobowych wydalają z moczem, kałem i śliną cząsteczki wirusa, którymi zakażają się ludzie na skutek inhalacji pyłów skażonych tymi wydalinami.

Dla gatunków wirusa: Haantan, Dobrava, Seoul, Saarema i Amur wektorami są gryzonie z rodziny Murinae - odpowiednio: dla serotypu Hantaan - Apodemus agrarius (mysz polna) występujacy w Chinach, Korei, Rosji i niektórych krajach europejskich, dla serotypu Dobrava Apodemus flavicollis (mysz leśna) występująca w Europie (5). Typ Seoul rozprzestrzeniony po całym świecie przenoszony jest przez szczury z gatunków Rattus norvegicus i Rattus rattus. Serotyp Amur występujący w Azji przenoszony jest przez gatunek Apodemus peninsulae. Wymienione gatunki wywołu- 
acute renal failure and proteinuria as well as the coagulation disorders. Therefore, due to the severe course mortality reaches $15 \%$.

The second group of viruses: Puumala, Tula, Topografov, Khabarowsk, Prospect Hill and Isla Vista infect rodents from the Arvicolinae family. In the case of infection with the Puumala species transmitted by Clethrionomys glareolus (red vole) (6), a set of symptoms with a benign self-limiting course, called nephropathia epidemica, develops. The Tula virus transmitted by Microtus arvalis (common vole) produces severe clinical syndromes with renal and pulmonary complications (7). The remaining species belonging to this group are considered to be nonpathogenic for humans.

For the group of viruses found on American continents, species belonging to the Sigmodontinae family are the hosts. The Andes virus found in Argentina and Chile is transmitted by the Oligoryzomys longicaudatus (Long-tailed rice rodent), Sin Nombre virus (USA, Mexico) transmitted by Peromyscus maniculatus. The viruses cause a set of symptoms called HPS (hantavirus pulmonary syndrome) characterized by a fulminant course with acute circulatory and respiratory failure and mortality at $40 \%(8)$.

In Poland, there occur infections with a history characteristic of HFRS and nephro-pathia epidemica which are characterized mainly by the involvement of kidneys, accompanied by symptoms of damage to other organs, eg. liver, blood vessel walls, lungs (cough and dyspnea). Additional pulmonary changes are a leading symptom in HPS. Nevertheless, in the majority of HPS patients, proteinuria and renal failure are also observed. It seems, therefore, that isolation of two different clinical syndromes associated with HV is not possible - hence it is postulated to identify the infection caused by HV with the common name: hantavirus disease or hantavirus fever (9). A similar name "Hantavirus-induced disease" functions in Poland and is used by the National Institute of Public Health and National Hygiene Institute in their epidemiological reports (Epimeld).

The incubation period of the disease lasts from 10 to 25 days. There are 5 phases of the disease: feverish one, hypotensive phase, oliguria, polyuria and recovery. The onset of the feverish phase is sudden, with flu-like symptoms, headaches and muscle aches, as well as myopia and blurred vision. After 3-4 days, the patient enters the hypotensive (shock) phase, in which a drop in blood pressure, fainting, and cardiac arrest may occur. The hemorrhagic diathesis, gastrointestinal bleeding increases and then symptoms of acute renal failure appear.

The next phase (oliguric phase) lasts up to 7 days when water and electrolyte disturbances appear, hemorrhagic diathesis persists, and brain and lung oede- ją zespół kliniczny nazywany HFRS. Charakteryzuje się on ostrą niewydolnością nerek oraz białkomoczem i zaburzeniami krzepnięcia. Z uwagi na ciężki przebieg śmiertelność sięga 15\%.

Druga grupa wirusów: Puumala, Tula, Topografov, Khabarowski, Prospect Hill i Isla Vista infekuje gryzonie z rodziny Arvicolinae. W przypadku infekcji gatunkiem Puumala przenoszonym przez Clethrionomys glareolus (nornica ruda) (6), rozwija się zespół objawów o łagodnym samoograniczającym się przebiegu noszący nazwę nefropatia epidemiczna (nephropathia epidemica). Wirus Tula przenoszony przez Microtus arvalis (Nornika zwyczajnego), wywołuje zespoły kliniczne o ciężkim przebiegu z powikłaniami nerkowymi i płucnymi (7). Uważa się, że pozostałe gatunki należące do tej grupy, nie są patogenami dla człowieka.

Dla grupy wirusów występujących na kontynentach amerykańskich gospodarzami są gatunki należące do rodziny Sigmodontinae. Wirus Andes występujący w Argentynie i Chile przenoszony jest przez Oligoryzomys longicaudatus (ryżaczek długoogonowy), wirus Sin Nombre (USA, Meksyk) przenoszony przez Pyeomyscus maniculatus (myszak leśny).Oba wirusy wywołują zespół objawów nazywany HPS (hantawirusowy zespół płucny) charakteryzujący się piorunującym przebiegiem z ostrą niewydolnością krążeniowo-oddechową i śmiertelnością na poziomie $40 \%$ (8).

W Polsce występują zakażenia o przebiegu charakterystycznym dla HFRS oraz nephropathia epidemica, które charakteryzują się zajęciem głównie nerek, z towarzyszącymi objawami uszkodzenia innych narządów np.: wątroby, ścian naczyń krwionośnych, płuc (kaszel i duszność). Zmiany płucne są wiodącym objawem w HPS, jednak u większości pacjentów z HPS obserwuje sie także białkomocz i niewydolność nerek. Wydaje się więc, że wyodrębnienie dwu różnych zespołów klinicznych związanych z HV nie jest możliwe - dlatego postulowane bywa określenie infekcji wywoływanych przez HV wspólną nazwą: choroba hantavirusowa (hantavirus disease) lub gorączka hantavirusowa (hantavirus fever) (9). Podobna nazwa „choroba wywołana przez hantavirusy" funkcjonuje w Polsce i używana jest przez Narodowy Instytut Zdrowia Publicznego Państwowy Zakład Higieny w meldunkach epidemiologicznych (Epimeld).

Okres wylęgania choroby wynosi 10-25 dni. Wyróżnia się 5 faz choroby: gorączkową, hipotensyjną, skąpomoczu, wielomoczu i zdrowienia. Początek fazy gorączkowej jest nagły, z objawami grypopodobnymi, bólami głowy i mięśni, a także krótkowzrocznością i zamglonym widzeniem. Po 3-4 dniach pacjent wchodzi w fazę hypotensyjną (wstrząsową),w której obserwowany jest spadek ciśnienia tętniczego krwi, omdlenia, może wystąpić zatrzymanie krążenia. Nasila się skaza krwotoczna, krwawienia z przewodu 
ma may occur. About $50 \%$ of deaths associated with HFRS occur during the oliguric phase. The phase of oliguria is followed by the polyuric phase, in which the diuresis increases. The characteristics of renal failure disappear at the end of the third week after the onset of the febrile phase (10).

In Europe, renal parameters after HFRS are considered to normalize (11). In the United States a significantly higher frequency of anti-hantavirus antibodies was observed among patients on dialysis with diagnosis of hypertensive nephropathy $(6.5 \%)$ and among all dialysis patients $(2.76 \%)$ vs. $0.25 \%$ in the healthy population (12).

Diagnosis of the disease is based on serological tests (ELISA, Western blot, IFL) detecting IgM class antibodies present from the 4th day, and the IgG class present from the 6th day after the onset of the symptoms. The most frequently identified viral serotypes in Europe and in Poland are Dobrava and Puumala. The only laboratory that constantly tests for $\mathrm{HV}$ infections is the Voivodship Sanitary and Epidemiological Station in Rzeszów. The use of PCR genetic testing in life-related diagnostics in humans is difficult due to the short-lived period of viral load lasting up to 4 days from the beginning of the febrile phase.

The treatment of this disease in Poland is symptomatic, and the majority of cases diagnosed in Poland were hospitalized. Severe cases required renal replacement therapy. There are no reports of treatment for the treatment of Rybavirin. Active prophylaxis (Hantavax) in Poland is not applied.

In prevention of the disease, it is important to avoid exposure to contaminated dust. Therefore the application of masks in a dusty, contaminated environment is recommended. What is more, the watering of dusty surfaces that could have been contaminated by rodents in order to avoid inhalation of dust can also be advised.

The risk groups include people exposed to direct or indirect contact with rodents such as: zoologists, foresters, soldiers, tourists, and rural population as well as other people exposed to contact with rodents excreta.

\section{EPIDEMIOLOGY OF HFRS IN POLAND AND THE WORLD}

Around 150.000-200.000 cases of HFRS are recorded annually in the world and about 300 of HPS cases. China is the country with the highest incidence of HFRS in the world, with the number of infections reaching 50.000 annually (and in epidemic years reaching up to 100,000). In terms of the number of HFRS infections, the European part of the Russian Federation comes in as second (with about 3-6 thousand cases per year). The incidence in the European part of Russia is 14.1-81.5/100,000 (including the republics of pokarmowego. Pojawiają się objawy ostrej niewydolności nerek. Kolejna faza (oligurii) trwa do 7 dni. Pojawiają się zaburzenia wodno- elektrolitowe, utrzymuje się skaza krwotoczna, może wystąpić obrzęk mózgu i płuc. W fazie oliguri występuje około 50\% zgonów związanych z HFRS. Po fazie oligurii następuje faza wielomoczu, w której zwiększa się diureza. Cechy niewydolności nerek ustępują pod koniec trzeciego tygodnia od początku fazy gorączkowej (10).

W Europie uważa się, że parametry nerkowe po przechorowaniu HFRS wracają do normy (11). W Stanach Zjednoczonych zaobserwowano istotnie większą częstość występowania przeciwciał anty-hantawirusowych wśród osób dializowanych z rozpoznaniem nefropatii nadciśnieniowej ( $6,5 \%$ ), jak i wśród ogółu osób dializowanych $(2,76 \%)$ vs $0,25 \%$ w populacji zdrowej (12).

Diagnostyka choroby opiera się na testach serologicznych (ELISA, Western blot, IFL) wykrywających przeciwciała klasy IgM obecne od 4 doby, oraz klasy IgG obecnych od 6 doby od wystąpienia objawów zachorowania. Najczęściej identyfikowane serotypy wirusa w Europie i w Polsce to Dobrava i Puumala. Jedynym laboratorium posiadającym stale testy w kierunku zakażeń HV jest Wojewódzka Stacja Sanitarno-Epidemiologiczna w Rzeszowie. Zastosowanie badania genetycznego PCR w diagnostyce przyżyciowej u ludzi jest utrudnione $\mathrm{z}$ uwagi na krótkotrwały okres wiremii trwający do 4 doby od początku fazy gorączkowej.

Leczenie tej choroby w Polsce jest objawowe, większość przypadków rozpoznanych w Polsce była hospitalizowana, ciężkie przypadki wymagały leczenia nerkozastępczego. Nie ma doniesień o stosowaniu w leczeniu rybaviryny. Profilaktyka czynna (Hantavax) w Polsce nie jest stosowana.

W zapobieganiu chorobie ma znaczenie unikanie narażenia na kontakt ze skażonym pyłem, stosowanie masek przy pracy w zapylonym, skażonym środowisku oraz polewanie wodą powierzchni zakurzonych, które wcześniej mogły być zanieczyszczone przez gryzonie, w celu uniknięcia inhalacji pyłów.

Do grup ryzyka zaliczane są osoby narażone na bezpośredni lub pośredni kontakt z gryzoniami: zoolodzy, leśnicy oraz ludność wiejska, żołnierze, turyści itp.

\section{EPIDEMIOLOGIA PRZYPADKÓW HFRS W POLSCE I NA ŚWIECIE}

$\mathrm{Na}$ świecie rocznie notuje się ok.150-200 tys. przypadków HFRS i ok. 300 przypadków HPS. Chiny są krajem o najwyższej na świecie zapadalności na HFRS, rokrocznie notowane jest ok. 50 tys. zakażeń (w latach epidemii do 100 tys.). Na drugim miejscu pod względem liczby zakażeń HFRS znajduje się europejska część Federacji Rosyjskiej (ok. 3-6 tys. przy- 
Bashkiria and Udmurtia, which are endemic regions of the disease). In the Far East regions of the Russian Federation, the incidence is smaller and amounts to 2 $/ 100,000$. Another Asian country is Korea which reports 1-2 thousand of infections annually (13) and it occupies the third position.

The incidence rate of HFRS in Europe in particular years fluctuates due to epidemics that overlap every 3-4 years for a constant number of infections characteristic for a given region. The country with the highest incidence in Europe is Finland where the number of cases ranges from around 1500 to about 2000 cases per year. In 2014, a record number of infections (3 754) was registered across Europe. In Poland, the number of infections then was also higher (54) and probably it was the "epidemic year" for Poland. In the following year, that is in 2015 there were 6 infections, 8 cases were registered in 2016 and 14 in 2017. Based on data from Poland, it is difficult to determine which years were the epidemic years except for 2014.

Reporting on the registration of infections of HFRS concerns Poland since 2004 (accession to EU structures). From that time until the end of May 2018, 132 cases of Hantavirus infections were identified. Only 5 cases came from the areas other than Podkarpacie region (3 cases from the Małopolskie voivodeship in the first quarter of 2013, 1 from the Opolskie voivodship in the fourth quarter of 2013, and 1 case in the first quarter of 2014 in the Łódź Voivodeship ). The incidence ranged from 0.02 to 0.14 per 100,000.

Each detection of the infection requires a notification to the State Sanitary Inspection under the number A 98.5 according to the ICD-10 classification, as well as to the European Centre for Disease Prevention and Control (ECDC).

\section{HFRS CASE REPORTS IN POLAND}

In 1973, the first case of HFRS was described by Mielnikow. He reported an infection in Wroclaw in a 36-year-old patient with acute kidney and liver damage who has had contact with rodents in an interview. After the exclusion of leptospirosis, the diagnosis was made on the basis of additional tests with an antigenic system developed by scientists from the former USSR, which in later years gained confirmation of specificity for the diagnosis of Hantavirus infections (14).

In 2004, under the leadership of Knap et al., another case of HFRS with severe course (jaundice, hepatorenal syndrome) was diagnosed which was recognized by WHO. This patient was a 46-year-old woman from the Podkarpackie province who was infected with Puumala. (15).

In 2007, in the province of Podkarpackie, Nowakowska et al. identified 17 cases of HFRS infections, padków rocznie). Zapadalność w europejskiej części Rosji wynosi 14,1-81,5/100 000 (wliczając republiki Baszkiria i Udmurcja, które są endemicznymi regionami choroby). Na Dalekim Wschodzie Federacji Rosyjskiej zapadalność jest mniejsza i wynosi 2/100 000. Trzecim w kolejności ilości zakażeń krajem jest Korea z 1-2 tys. zakażeń rocznie (13).

Zapadalność w Europie w poszczególnych latach podlega wahaniom $\mathrm{z}$ uwagi na epidemie nakładające sie co ok. 3-4 lata na stałą liczbę zakażeń, charakterystyczną dla danego regionu. Krajem o największej zapadalności w Europie jest Finlandia z ok. 1500 do ok. 2000 przypadków rocznie. W 2014 roku w całej Europie zarejestrowano rekordową liczbę zakażeń (3754). W Polsce również liczba zakażeń była wtedy większa (54) i był to prawdopodobnie dla Polski „rok epidemii “. W kolejnym 2015 r. było 6 zakażeń, 8 przypadków w 2016 i 14 w 2017 r. Na podstawie danych z Polski trudno ustalić, które lata były latami epidemii z wyjątkiem roku $2014 \mathrm{r}$.

Sprawozdawczość dotycząca rejestracji zakażeń na HFRS dotyczy Polski od 2004 r. (przystąpienie do struktur UE). Od tego czasu do końca maja 2018 roku zidentyfikowano 132 przypadki zakażeń wirusem Hanta. Jedynie 5 przypadków pochodziło z innych niż Podkarpacie obszarów Polski (3 przypadki z woj. małopolskiego w I kwartale 2013 roku, 1 zachorowanie z terenu woj. opolskiego w IV kwartale 2013 roku, oraz 1 zachorowanie w I kwartale 2014 roku w woj. łódzkim). Zapadalność wynosi od 0,02 do 0,14 na 100 tys.

Wykrycie zakażenia wymaga zgłoszenia do Państwowej Inspekcji Sanitarnej pod numerem A $98.5 \mathrm{wg}$ klasyfikacji ICD-10, jak również do Europejskiego Centrum ds. Zapobiegania i Kontroli Chorób( ECDC).

\section{OPISY PRZYPADKÓW HFRS W POLSCE}

Pierwszy przypadek HFRS opisał w 1973 r. Mielnikow we Wrocławiu u 36 letniego pacjenta z ostrym uszkodzeniem nerek i wątroby, mającego w wywiadzie kontakt z gryzoniami. Po wykluczeniu leptospirozy, rozpoznanie postawiono na podstawie dodatnich testów z układem antygenowym opracowanym przez naukowców z obecnego ZSRR, który w późniejszych latach uzyskał potwierdzenie swoistości dla rozpoznawania zakażeń hantavirusowych (14).

W 2004 roku pod kierownictwem Knapa i wsp. rozpoznano kolejny (pierwszy oficjalnie uznany przez WHO) przypadek HFRS z ciężkim przebiegiem (żółtaczką, zespołem wątrobowo-nerkowym), z zakażeniem serotypem Puumala u 46 letniej kobiety z woj. podkarpackiego (15).

W 2007r. w woj. podkarpackim Nowakowska i wsp. zidentyfikowali 17 przypadków zakażeń HFRS, z czego 13 świeżych zachorowań było leczonych i po- 
and 13 of these new cases were treated and confirmed serologically in the period from August to December 2007. The course of the disease was described, the regions of endemic virus were identified and it was shown that both the Dobrava and Puumala serotypes were responsible for the infections. 7 out of the 13 reported cases, had a severe course and 5 required periodical hemodialysis (16).

Therefore, the Podkarpacie region has become the target of further research involving the analysis of the geographic environment in the context of the identification of infected rodents. In 2014, a study by Michalski et al. was published, in which the screening of patients suspected of Hantavirus infection was combined with a simultaneous collection of animals from areas where the patients with confirmed infection came from. Among 70 patients with clinical symptoms suspected of HFRS, 18 had anti-HV antibodies, 11 were reported to have anti-Puumala and 7 cases had antiDobrava antibodies. The 13 patients had antibodies of both classes, that is the $\operatorname{IgM}$ and $\operatorname{IgG}$, and 5 patients had the IgG class. The examination of the 194 caught rodents, the genetic material of the virus was identified in 17 (in 10 rodents of the Dobrava species, in 5 Tula, and in 2 cases of Puumala) (17).

\section{POPULATION SCREENING IN POLAND.}

In 1989 Panasiak et al. examined 1158 human sera (blood donors, farmers, laboratory staff, chronically dialyzed patients, people with suspected leptospirosis and a group of patients with acute renal failure and fever) and 125 animal sera (91 from laboratory animals and 34 from wild animals living in the east of Poland) (18). Positive titres of the antibodies were detected in 1 laboratory mice and 6 people. None of these people showed HFRS-specific symptoms at that time, which was important because the researchers did not have the possibility of identifying the antibodies in the IgM and IgG classes separately.

In 2007, a study by Sadkowska-Todys et al. was published, in which she examined subjects suspected of having suffered from nephropathia epidemica in the past or with acute symptoms and suspected nephropathia epidemica as well as healthy individuals from the risk groups (foresters from the Silesia region and zoologists). Positive antibodies indicating a contact with the virus were found only in the zoologists group (19).

In the study of Grygorczuk et al. from 2008 the results of screening serological tests carried out among foresters from the Podlasie province and WarmianMasurian province (59 people) and among foresters from the Białystok region (10 people). Anti-Puumala antibodies in the IgG class were found in 4 people twierdzonych serologicznie w okresie od sierpnia do grudnia 2007 r. Opisano przebieg choroby, zidentyfikowano rejony występowania endemicznego wirusa oraz wykazano, że za zachorowania odpowiedzialne były zarówno serotyp Dobrava, jak i Puumala. Na zanotowanych 13 przypadków aż 7 przypadków miało przebieg ciężki, a 5 wymagało okresowej hemodializoterapii (16).

Podkarpacie stało się celem dalszych badań polegających na analizie środowiska geograficznego w kontekście identyfikacji zakażonych gryzoni. W 2014 roku opublikowano badanie Michalskiego i wsp., w którym połączono badanie przesiewowe pacjentów podejrzanych o zakażenie wirusem Hanta oraz równolegle przeprowadzono odłów zwierząt $\mathrm{z}$ terenów, skąd pochodzili pacjenci z potwierdzonym zakażeniem. Wśród 70 pacjentów z klinicznymi objawami podejrzanymi o HFRS u 18 stwierdzono obecność przeciwciał anty HV - z tego u 11 anty- Puumala, a u 7 anty-Dobrava. 13 pacjentów posiadało p-w ciala w obu klasach - IgM i IgG, natomiast 5 osób w klasie IgG. Spośród 194 odłowionych gryzoni u 17-u osobników zidentyfikowano materiał genetyczny wirusa (u 10 gryzoni gatunku Dobrava, u 5 Tula, a w 2 przypadkach Puumala) (17).

\section{POPULACYJNE BADANIA PRZESIEWOWE W POLSCE .}

Panasiak i wsp. w 1989 roku przebadali 1158 surowic ludzkich (krwiodawcy, rolnicy, personel laboratoryjny, osoby przewlekle dializowane, osoby z podejrzeniem leptospirozy oraz grupa chorych z ostrą niewydolnością nerek i gorączką) oraz 125 surowic zwierzęcych (91 od zwierząt laboratoryjnych i 34 od dziko żyjących w rejonie wschodniej Polski) (18). Dodatnie miana przeciwciał wykryto u 1-ej myszy laboratoryjnej i 6 osób. Żadna $\mathrm{z}$ tych osób nie manifestowała w danym czasie objawów charakterystycznych dla HFRS, co jest istotne z uwagi na to, że badacze nie mieli możliwości oddzielnej identyfikacji przeciwciał w klasach IgM i IgG.

W 2007 roku ukazało sie badanie Sadkowskiej-Todys i wsp.,w którym przebadano osoby podejrzane o przebycie nephropathia epidemica w przeszłości lub z ostrymi objawami z podejrzeniem nephropathia epidemica oraz osoby zdrowe z grup ryzyka (leśników z rejonu Śląska oraz zoologów). Dodatnie przeciwciała świadczące o kontakcie $\mathrm{z}$ wirusem stwierdzono jedynie w grupie zoologów (19).

W badaniu Grygorczuka i wsp. z 2008r. opublikowano wyniki przesiewowych badań serologicznych przeprowadzonych wśród leśników z rejonu woj. podlaskiego i warmińsko-mazurskiego (59 osób) oraz wśród leśników z Białostocczyzny (10 osób). Przeciwciała anty-Puumala w kl. IgG stwierdzono u 4 osób w całej grupie, co stanowi 5,7\% badanych, natomiast przeciwciała 
from the whole group, which constituted $5.7 \%$ of the examined population, while anti-Hantaan antibodies were present in the IgG class in 2 people (2.9\%) (20).

In 2010, Knap et al. confirmed the presence of antihantavirus antibodies in the IgG class in 4 out of 161 foresters $(2.5 \%)$ from the Lublin region. $1.2 \%$ of the people had anti-Dobrava antibodies (21).

In 2014, Żukiewicz-Sobczak et al. studied 216 sera of foresters from south-eastern Poland and confirmed the presence of anti-hantavirus antibodies in 9 of them. These were antibodies of anti Dobrava / Hantaan (3 cases) and anti-Puumala (5 cases) (22).

In 2017, Wróblewska-Euczka et al. published the results of the study conducted on the sera of 820 foresters from 32 forest districts in Poland $(23,24)$. The sera were analyzed for the presence of anti Dobrava / Hantaan antibodies and anti-Puumala antibodies in the IgM and IgG classes. There were 25 positive antiDobrava / Hantaan and 12 anti-Puumala results.

\section{THE INCIDENCE OF HANTA VIRUS AMONG RODENTS}

In 2004, the results of the research by Song et al. conducted on the rodents of Microtus arvalis and Clethrionomys glareolus (25) species caught in the Lódź region were published. In six of the rodents harvested in 1995, the sera examined by indirect immunofluorescence confirmed the presence of antibodies characteristic of the Puumala type.

In 2015, a study by Sadkowska-Todys et al. was published, which confirmed the presence of positive anti-hantavirus antibodies in 55 of 564 rodents in the vicinity of Lesko and Brzozów (26).

The research conducted by Gu et al. in the vicinity of Łódź (Huta Dłutowska, Boginia, Kurowice) in 2013 resulted in the identification of 3 new species of viruses of unknown pathogenicity to humans: Boginia - isolated from the species Neomys fodiens (27), Seewis virus isolated from three various species of shrews, and the Nova virus found in moles (Talpa europea) (28).

On the basis of research carried out by Ali et al. (29) in the vicinity of Mikołajki (Warmińsko-Mazurskie province) and Rosenfeld et al. (30) in the Podkarpackie region, the genetic material of Puumala virus from rodents (M. glareolus) was isolated. Additionally, basing on the difference in the genome of the virus both researches confirmed the presence of a number of genetic lineages within the same viral species.

\section{SUMMARY}

The results of the tests described above confirm that Hanta viruses occur in the environment in many places in Poland. It is probable that the infections anty - Hantaan w klasie IgG u 2 osób (2,9\%) (20).

W 2010 r. badanie Knapa i wsp. potwierdziło obecność przeciwciał anty - hantawirusowych w kl. IgG u 4 spośród 161 leśników (2,5\%) z terenów Lubelszczyzny. $1,2 \%$ osób posiadało przeciwciała anty-Dobrava (21).

W 2014 roku Żukiewicz -Sobczak i wsp. przebadali 216 surowic leśników z Polski południowo- wschodniej i potwierdzili obecność przeciwciał anty - hantavirusowych u 9 z nich. Były to przeciwciała anty Dobrava/ Hantaan (3 surowice) i anty-Puumala (5 surowic) (22).

W 2017 r. Wróblewska-Euczka i wsp. opublikowali wyniki badania surowic 820 leśników z terenu 32 nadleśnictw w całej Polsce $(23,24)$. Surowice poddano analizie zarówno na obecność przeciwciał anty Dobrava/Hantaan oraz anty -Puumala w klasach IgM i IgG. Stwierdzono 25 dodatnich wyników anty-Dobrava / Hantaan oraz 12 anty -Puumala.

\section{WYSTĘPOWANIE NOSICIELSTWA WIRUSA HANTA WŚRÓD GRYZONI}

W 2004 r opublikowano wyniki badań Songa i wsp. nad odłowionymi w rejonie Łodzi gryzoniami z gatunku Microtus arvalis oraz Clethrionomys glareolus (25). U 6-ciu spośród odłowionych w $1995 \mathrm{r}$. gryzoni, w badanych surowicach metodą immunofluorescencji pośredniej wykryto przeciwciała charakterystyczne dla typu Puumala.

W 2015 r. opublikowano badanie Sadkowskiej-Todys i wsp., które potwierdziło obecność dodatnich przeciwciał anty - hantavirusowych u 55 z 564 gryzoni z okolic Leska i Brzozowa (26).

Badania przeprowadzone przez $G u$ i wsp.w okolicach Łodzi (Huta Dłutowska, Boginia, Kurowice) w roku 2013 zaowocowały identyfikacją 3 nowych gatunków wirusów o nieznanej jeszcze patogenności dla ludzi: Boginia - wyizolowanego z gatunku Neomys fodiens (27), wirusa Seewis wyizolowanego od trzech różnych gatunków ryjówek, oraz wirusa Nova występującego u kretów (Talpa europea) (28).

$\mathrm{Na}$ podstawie badań, które przeprowadzili Ali i wsp. (29) w okolicach miejscowości Mikołajki (woj. warmińsko-mazurskie) oraz Rosenfeld i wsp. (30) w rejonie Podkarpacia wyizolowano materiał genetyczny wirusa Puumala od gryzoni (M. glareolus). Ponadto obydwa badania dowiodły na podstawie różnic w genomie wirusa występowania kilku różnych linii genetycznych w obrębie tego samego gatunku wirusa .

\section{PODSUMOWANIE}

Wyniki wyżej opisanych badań potwierdzają, że wirusy Hanta występują w środowisku w wielu miejscach na terytorium Polski. Prawdopodobne jest twierdzenie, że zakażenia spowodowane tymi wirusa- 
caused by these viruses occur in a larger area than just the Podkarpacie region (now considered to be an endemic region to the hantavirus disease). In the view of the prevalence of the antibodies against Hanta viruses among people from the risk group, it also seems that hantavirus is an important factor shaping the health of these groups. The predominant symptoms of Hanta virus infection are not particularly specific because they resemble flu-like symptoms with high fever, which cannot be treated with non-steroidal anti-inflammatory drugs.

It should be presumed that the infection caused by Hanta viruses may be the direct cause of an acute kidney damage, which resembles the flue-like symptoms with high fever and various types of gastric dysfunctions as well as with thrombocytopenia.

\section{REFERENCES}

1. Hepojoki J, Strandin T, Lankinen H, et al. Hantavirus structure-molecular interactions behind the scene. J Gen Virol 2012; 93(8) :1631-44.

2. Gavrilovskaya IN, Brown EJ, Ginsberg MH, et al. Cellular entry of hantaviruses which cause hemorrhagic fever with renal syndrome is mediated by $\beta 3$ integrins. $\mathrm{J}$ Virol 1999; 73(5):3951-59.

3. Kraus AA, Raftery MJ, Giese T, et al .Differential antiviral response of endothelial cells after infection with pathogenic and nonpathogenic hantaviruses. J Virol 2004;78(12):6143-50.

4. Kanerva M, Mustonen J, Vaheri A, Pathogenesis of Puumala and other hantavirus infections. Rev in Med Virol 1998: 8(2) :67-86.

5. Sibold C, Ulrich R, Labuda M, et al. Dobrava hantavirus causes hemorrhagic fever with renal syndrome in central Europe and is carried by two different Apodemus mice species. J Med Virol 2001;63(2):158-67.

6. Settergren B, Clinical aspects of nephropathia epidemica (Puumala virus infection) in Europe: a review. Scand J Inf Dis 2000;32(2):125-32.

7. Klempa B, Meisel H, Räth S, et al Occurrence of renal and pulmonary syndrome in a region of northeast Germany where Tula hantavirus circulates. J Clin Microbiol 2003;41(10):4894-7.

8. Hjelle B,Glass GE, Outbreak of hantavirus infection in the Four Corners region of the United States in the wake of the 1997-1998 El Nino-Southern Oscillation. J Inf Dis 2000;18(5):1569-73.

9. Clement J, Maes P, Lagrou K, et al. A unifying hypothesis and a single name for a complex globally emerging infection: hantavirus disease. Eur J Clin Microbiol \& Inft Dis $2012 ; 1(31): 1-5$

10. Knap JP,Trybusz A,Haemorrhagic fever with renal syndrome (HFRS)--Hantavirus infection disease appearing in Poland. Pol Merk Lek 2006;21(125): 411-17.

11. Miettinen MH, Mäkelä SM, Ala-Houhala IO, et al. Tubular proteinuria and glomerular filtration 6 years after puumala hantavirus-induced acute interstitial nephritis. Nephron Clinical Practice 2009;112(2):115-20. mi występują na większym obszarze niż Podkarpacie (obecnie uznany za endemiczny dla choroby hantawirusowej). W świetle rozpowszechnienia przeciwciał przeciwko wirusom Hanta wśród osób z grup ryzyka wydaje się też, że choroba hantawirusowa jest istotnym czynnikiem kształtującym stan zdrowia tych grup. Dominujące objawy zakażenia wirusami Hanta nie są szczególnie specyficzne, ponieważ przypominają objawy grypopodobne z wysoką gorączką, nie poddające się terapii niesteroidowymi lekami przeciwzapalnymi.

Należy domniemywać, że zakażenie spowodowane wirusami Hanta może być bezpośrednią przyczyną ostrego uszkodzenia nerek, w obrazie którego występują objawy grypopodobne z wysoką gorączką i różnego rodzaju dysfunkcjami gastrycznymi, a także z małopłytkowością.

12. Glass GE, Watson AJ, LeDuc JW, et al Infection with a ratborne hantavirus in US residents is consistently associated with hypertensive renal disease. J Inf Dis 1993;167(3):614-20.

13. Слонова РА, Ткаченко ЕА,Иванис ВА, at al Геморрагическая лихорадка с почечным синдромом: современные аспекты экологии, этиологии, эпидемиологии, иммунопатогенеза, диагностики, клиники и лечения, Примполиграфкомбинат, 2006:196.

14. Mielnikow W. Przypadek zakaźnej gorączki krwotocznej (nephroso-nephritis haemorrhagica) Wiad.Lek $1973 ; 26: 173-6$

15. Knap JP., Brzostek T, Rączka A, et al. Przypadek gorączki krwotocznej z zespołem nerkowym (HFRS). Pol Merk Lek, 2006;125:474-6.

16. Nowakowska A., Heyman P, Knap JP, et al. The first established focus of hantavirus infection in Poland, 2007. Ann Agric Environ Med 2009;16(1):79-85.

17. Michalski A, Niemcewicz M, Bielawska-Drózd A, et al. Surveillance of hantaviruses in Poland: a study of animal reservoirs and human hantavirus disease in Subcarpathia. Vector-Borne and Zoonotic Diseases 2014; 14(7): 514-22.

18. Panasiak W, Wleklik M, Oraczewska A, et al. Serological studies of haemorrhagic fever with renal syndrome (HFRS) in Poland. Preliminary report. Acta Microbiol Pol 1989;38(1):63-7.

19. Sadkowska-Todys M, Gut W, Baumann A, et al. Ocena problemu występowania zakażeń ludzi hantawirusami na terenie Polski, ze szczególnym uwzględnieniem wirusa Puumala. Przegl Epidemiol 2007;61(4): 497-503.

20. Grygorczuk S, Pancewicz S, Zajkowska J, et al. Detection of anti-hantavirus antibodies in forest workers in the north-east of Poland. Przegl Epidemiol 2008;62(3):531-7.

21. Knap JP, Nowakowska A, Dutkiewicz J, et al.. Detection of antibodies against hantaviruses in forestry workers of the Roztoczanski National Park and Puławy forest inspectorate (Lublin macroregion). Preliminary report. Med Ogólna 2010;16:201-16. 
22. Żukiewicz-Sobczak W, Zwolinski J, Chmielewska-Badora J, et al. Prevalence of antibodies against selected zoonotic agents in forestry workers from eastern and southern Poland. Ann Agric Environ Med 2014;21(4).

23. Wróblewska-Łuczka P, Chmielewska-Badora J, Zwoliński J, et al. Exposure to infection with Hantavirus (serotype Dobrava/Hantaan) among forestry workers in Poland Folia Forestalia Polonica 2017;59(3):198-206.

24. Wróblewska-Łuczka P, Chmielewska-Badora J,Zwoliński J, et al. Seroepidemiologic Evaluation of Exposure to In-fection with Hantavirus (serotype Puumala) Among Forestry Workers in Poland. Baltic Forestry 2017

25. Song J W, Baek L J, Song KJ, et al.. Characterization of Tula virus from common voles (Microtus arvalis) in Poland: evidence for geographic-specific phylogenetic clustering. Virus Genes 2004;29(2): 239-47.

26. Sadkowska-Todys M, Dudek-Godeau D, Kamińska S, et al. Occurrence and maintenance of hantavirus infections among rodent populations in their natural habitat-results of a field study from Podkarpackie province, Poland 2010-2012 Przegl Epidemiol 2015; 69(2):283-8.

27. Gu S H, Markowski J, Kang HJ, i in. Boginia virus, a newfound hantavirus harbored by the Eurasian water shrew (Neomys fodiens) in Poland. Virology Journal 2013;10(1):160.
28. Gu SH, Hejduk J, Markowski J, et al. .Co-circulation of soricid-and talpid-borne hantaviruses in Poland. Infection, Genetics and Evolution 2014;28:296-303.

29. Ali HS, Drewes S, Sadowska ET, et al..First molecular evidence for Puumala hantavirus in Poland. Viruses 2014;6(1):340-53.

30. Rosenfeld UM, Drewes S, Ali HS, et al. A highly divergent Puumala virus lineage in southern Poland. Arch. Virol 2017;162(5):1177-85.

Received: 7.08.2018

Accepted for publication: 25.10.2018

Otrzymano: 7.08.2018 r.

Zaakceptowano do publikacji: 25.10.2018 r.

\section{Author for correspondence:}

Adres do korespondencji:

Agnieszka Woźniak-Kosek

awozniak-kosek@wim.mil.pl

Wojskowy Instytut Medyczny

ul. Szaserów 128

04-141 Warszawa 